Vol. 1, 2019

\title{
The Swiss Model of Direct Democracy
}

\author{
Prof. Dr. mult. Miroslaw Matyja Dr. h.c. \\ Logos International University / USA \\ Polish University Abroad in London; \\ Selinus University in Bologna/Italy; \\ Indian Management School and Research Centre in Mumbai / India \\ m.matyja@sunrise.ch
}

\begin{abstract}
Due to the challenges that modern representative democracy is facing, citizens and politicians of various countries are looking for new solutions and ways to ensure the optimal functioning of their political and decision making system. In this context, Switzerland appears to be a country relatively immune to the current crisis. Why is that? As a direct democracy where the rule of the people remains the fundamental principle, it provides its citizens with instruments: referendum, popular initiative, popular veto, which allow them to resolve any problems that arise both on the national and local level. The essential characteristic of the Swiss system, which is also its main strength, is that unlike other European democracies it grants its citizens full power over their homeland, making them the actual sovereign. The author of this article discusses various aspects of the Swiss model of democracy and suggests that it offers the best solutions for the optimal development of any country.
\end{abstract}

Keywords. Direct Democracy, Swiss Political System, Switzerland, Referendum, Federalism

\section{The Historical Determinants of the Swiss Political System}

The history of Switzerland is undoubtedly the key to understanding its political system and the mechanisms of its institutions. Despite the fact that its past, when compared to other countries, seems rather short and "meager", the evolution of Switzerland's political and social system can be described as brimming with original solutions (Czeszejko-Sochacki, 1999)

In ancient times, the area of the modern Switzerland was populated by Rhaetian and Celtic tribes. The name Helvetia comes from the Helvetii, the representatives of a Celtic tribe that settled in the Aare valley. However, the beginnings of modern Swiss state date back to the August 1, 1291, when three 
cantons - Uri, Schwyz, and Unterwalden - formed a confederation ${ }^{1}$ and made an alliance in order to jointly defend their lands against the Habsburgs. In this way, a so-called eternal union was made that would later become the foundation of the Swiss state (Matyja, 2010).

This pact, known as Eidgenosenschaft - i.e., "a union made under an oath" (Baur, 1979) - was confirmed by a special declaration, the so-called Federal Letter, which was also the first political act of the Swiss Confederacy. The citizens of the cantons, i.e., the signatories of the pact, expressed their belief regarding the alliance's permanence and declared mutual aid in defending their liberty and sovereignty. They also pledged not to recognize any settlements imposed on them by an external power and to settle any disputes by peaceful arbitration (Wojtowicz, 1976).

At first, the document was classified. Its content was not revealed before the battle of Morgarten in $1315^{2}$. Later, it was lost and eventually found in an archive in Stans in 1760. The document was translated and published in German (Matyja, 2010). The Swiss statehood continued to evolve throughout the subsequent centuries, and its political system underwent many changes. Despite the diversity in culture, language and religion, the additional cantons and communes that joined the confederation retained their sovereignty (Frey, 2005).

A turning point the history of Switzerland occurred in the late eighteenth century when the French army, led by Napoleon Bonaparte, occupied its territory and overthrew the existing political and social order. The direct cause for the French army's invasion were the inter-cantonal riots. In July 1798, undoubtedly influenced by the French Revolution, the citizens of the canton of Waadt - threatened by the authorities of the canton of Berne - sought the help of the Napoleonic army. After a number of clashes, the French conquered Berne and the whole Switzerland. On April 12, 1789, in the city of Aarau, the constitution of the so-called Helvetic Republic was officially proclaimed. Modeled after France, it was established as a centralized, unitary state. ${ }^{3}$ Drawn up in Paris, the constitution was an attempt at combining the progressive and enlightened ideas born by the French Revolution (Warszawa, 1997) with the concept of a state governed top-down, which - up to that point - was a notion foreign to federal Switzerland. The changes introduced by the constitution of the Helvetic Republic were essential to the cantons' status and limited their competencies. The union of sovereign countries was replaced with a unitary state without any borders between the cantons, which, following the French example, were renamed as "departments." In the summer of 1802, the French army withdrew from the Helvetic Republic by the order of Napoleon Bonaparte. The reasons were the Swiss' growing protests and the cold calculation of Napoleon himself,

\footnotetext{
${ }^{1}$ A confederation is a loose union of states based on an agreement made usually in order to pursue a common foreign policy. The states remain sovereign and, as a rule, there is no centralized power, author's note.

${ }^{2}$ During the Battle of Morgarten (November 13, 1315) the citizens of the cantons of Uri, Schwyz, and Unterwalden defended their rights to independence from the Habsburgs. It took place near Morgarten in the canton of Zug, author's note.

${ }^{3}$ A unitary state is characterized by internal political and administrative unity. All of its administrative units are organized identically and subordinated to its central authorities (author's note).
} 
who expected the French to soon come back to the Republic as the saviors of a divided country. After the French left, the Swiss could independently attempt at reforming their state. However, even adopting the so-called Second Constitution of the Helvetic Republic did not put an end to the internal unrest and riots. The whole of Switzerland was ridden with rebellions and conflicts. The advocates of the canton's sovereignty and the federal structure of the state rose to prominence. Due to this, on February 19, 1803, Napoleon imposed upon Switzerland a new constitution - the so-called Act of Mediation -, which revived the principle of federalism. The Act came fully into effect on March 10, 1803, ending the Helvetic Republic and, as a result, recreating the former administrative structure of the state (Aleksandrowicz, 2009).

The political system imposed by France did not survive long. Centralizing a confederation of free states proved to be impossible. On the other hand, the Act of Mediation turned out more durable with its effects still visible even in 1848 , when the new constitution was being prepared ${ }^{4}$.

The Act limited the competencies of the federal authorities to the following domains: foreign policy, military, ratifying tariffs, and mediation in inter-cantonal conflicts. At the beginning of the nineteenth century, these competencies belonged to the assembly of the cantons' representatives, and in the period between its sessions they belonged to the Landmann (the president), who also represented Switzerland abroad. At that time, however, the confederations' foreign policy was still strictly dependent on France (Würgler, 2011).

It should be emphasized that the time during which the Act of Mediation had been in effect, the confederation experienced a political stabilization. Due to being strongly dependent on France, however, Switzerland was highly sensitive to political events in other countries. The fall of Napoleon in 1814 also marked the end of the political system based on the Act of Mediation. The first half of the nineteenth century, until 1848, was a very difficult era for Switzerland. Great changes that occurred in the areas of politics, society, economy, and technology transformed the country's and its people's life.

The decision regarding the further status of the confederation was made at the Congress of Vienna, during which, on March 20, 1815, the then Swiss state was granted neutrality and inviolability of its territory. The European powers agreed that a neutral Switzerland would be a perfect buffer zone between France and Austria, thus, contributing to the political stability in Europe. In the meantime, Switzerland regained its confederation's territories and, on August 7, 1815, the 22 federated states signed an agreement - an inter-cantonal pact - that made Switzerland a federation, as opposed to its previous status as confederation. ${ }^{5}$ Despite this, the union has retained its traditional name, the Swiss

\footnotetext{
${ }^{4}$ The new document included provisions that regulated issues such as the separation of church and state, standardization of weights and measures, currency, legislation, and military, author's note.

${ }^{5}$ Federation, as opposed to confederation, is a state that comprises autonomous parts under a common (federal) government. The parts that constitute a federation have an internal autonomy and can make their own laws in certain domains. The common factors are, however, the currency, foreign policy, and defense, author's note.
} 
Confederation (German Schweizerische Eidgenossenschaft), which refers to the alliance made between the three cantons on the Rütli mountain in 1291 (Wojtowicz, 1976).

Around 1830, political thinking changed to be more favorable to the idea of returning to a centralized state. There were also attempts at discrediting the inter-cantonal pact and the assembly of the cantons' representatives.

In the years 1830-31, democratic revolutions occurred in twelve cantons, leading to a replacement of the former authorities with modern democratic institutions. However, citizens still lacked a direct influence on legislation and decision-making. Between 1831 and 1835, there began attempts at modernizing the federal pact of 1815 . In the early 1830 s, many projects that aimed at revising the pact were made but did not yield any positive results. Both the opposition during the 1830-31 constitutional debates and the social movements of 1839-41 demanded the right to veto political decisions. Today, this right can be considered as the precursor of modern referend (Büchi, Braun, Kaufmann, 2013). The first veto was introduced in the canton of St. Gallen in 1831. As a democratic instrument, veto was not practical since it did not pose a threat to the liberal parliamentary democracy. The democratic opposition was still too weak to be able to efficiently utilize the right to veto. Finally, in 1848 , the assembly of the cantons' representatives declared its own dissolution, which began the modernization of the federal state and changed the 1815 pact into a constitution. The changes, later named as the Bern Project, were accepted by fourteen cantons and one half-canton. A city in which a given session of the parliament was taking place was temporarily considered the capital of the country (Matyja, 2016).

\section{1) The Constitution of the Swiss Confederation}

In 1847, a civil war broke out between the Roman Catholic and the Protestant cantons. Catholics tried to prevent the strengthening of the central power, which was the goal of the then ruling representatives of the Radical Party. The hostilities lasted for a month and resulted in about 100 deaths. It was the last significant armed conflict in Swiss territory. Since then, the country has never experienced the horror of war. As a result, in 1848, the federal constitution was drawn up, and its announcement marked a turning point in the shaping of the Swiss political system. The constitution introduced a system of state governance based on the instrument of direct democracy, while leaving the cantons and the communes the right to self-govern on local issue (Manatschal, 2013). In the new constitution, the state declared itself as religiously neutral and adopted the principle of territoriality according to which multilingual Switzerland legally acknowledged every language used within its borders. All linguistic communities acquired the right to be - proportionally to their size - represented in the state's political institutions (Marczerwska-Rytko, 2011).

The new constitution comprised of a preamble and three chapters that contained 114 articles, as well as interim provisions (Pogorzelska-Kliks, 2007). The confederation of cantons was officially replaced with 
a federation whose members - the cantons - had to voluntarily give up a certain part of their sovereign rights in order to submit to the new power. The new federation retained the traditional name of Confederation and obliged itself to maintain the unity of the Swiss nation while ensuring internal order and peace. In this way - after gaining competence in foreign policy making, declaring war and peace, organizing the military, introducing tariffs, establishing postal and monetary systems - the federation claimed the right to intervene in the case of internal conflicts between cantons or a potential civil war (Pogorzelska-Kliks, 2007).

Apart from guaranteeing itself international independence and internal peace, the federation set itself two main goals: the protection of the cantons' rights and liberties, and the pursuit of citizens' general prosperity. Among the cantons' competencies, the schooling system, judiciary, legislation and police remained. The union guaranteed all of its citizens freedom of religion, speech, and association, as well as the right to assembly. The essential fact is that, from the very beginning, the federation ambitiously intended to create a Swiss nation. In order to do that, the freedom to settle was introduced, which meant that every citizen of the new Swiss state had the right to choose a place to live on the federation's territory without the risk of losing any of their basic rights.

However, the most significant innovation introduced by the Constitution of 1848 was undoubtedly the establishment of the legislative and the executive arms of the central authority: the parliament, the government, and the federal tribunal. The parliament - the Federal Assembly - elected in general elections, was made up of two houses: the National Council, which represented the nation, and the Council of States (two deputies from each canton). An important novelty was the executive power, the Federal Council, that consisted of seven members representing different cantons, political parties, as well as linguistic and religious groups. The first Federal Council was elected on December 16, 1848, and it adopted a system of collective decision-making (the act of May 16, 1849). ${ }^{6}$ On November 6, 1848, the first assembly of the two houses of the Federal Parliament took place in Bern, which was chosen to house the authorities of the newly established state (Matyja, 2019).

Apart from establishing the new state order, the federal constitution of 1848 included the possibility of amending it. The amendments could not only be made through the obligatory constitutional referendum, but also through popular initiative, i.e., by the will of ordinary citizens. This set up the framework for the contemporary liberal government and its policy of modernization. The constitution of 1848 should be considered as a declaration of will: at that time, democracy and the Swiss nation, as well as the nation state and the federal system, were still being defined as the young state's goal - they were not yet a reality.

\footnotetext{
${ }^{6} C f$. Bundesblatt no. 34 of July 26, 1873, http://www.admin.ch/opc/de/federal-gazette/1873/index_34.html, accessed August 10, 2019.
} 
The process of centralizing and limiting the cantonal power in favor of the federal authority in Switzerland was not unproblematic. The cantonal constitutions could not include any regulations that would contradict the new federal order and had to provide the possibility to be amended at the majority of citizens' will. Those constitutions, as well as the Federal Constitution, were repeatedly amended between 1848 and $1874 .^{7}$ The most important amendment was introduced in 1874, although - despite many changes - it was still a continuation of the political system established in 1848 . The changes introduced in the new constitution focused mainly on transferring some of the commercial competencies from the cantonal level to the federal one and on allowing the unification of civil law, especially its commercial branch (Czeszejko-Sochacki, 2000). The fundamental principles of the Swiss political system, i.e., the provisions determining the rights of the communes and cantons and the functioning and scope of the federation's competencies, remained unchanged (Rybicki, 1970).

The 1874 revision of the Constitution was not thorough and it retained basic federal institutions, such as a bicameral parliament, the Federal Council, as well as regulations concerning citizens' rights and liberties. The modified constitution increased the competencies of the central power, specifically in military issues. The Federal Government took upon itself the responsibility for the total of military affairs and commercial law. The federation gained a significant influence over religious matters. Also, the competencies of the Federal Supreme Court were expanded regarding the conflicts between the cantons and the central government. ${ }^{8}$

The most important amendment to the 1874 constitution was the introduction of the optional referendum, which affected the development of Switzerland's constitutional system and the form of its political system as a whole. The amended constitution granted the central government essential competencies, but its decisions had to be implemented in stages since the authorities had to take into consideration the attitudes and the mood of the citizens taking part in a referendum. The amendments that extended the competencies of the Federal Council included the introduction of a common currency and changes resulting from the population growth and the industrial revolution (among them the people's right to legislative initiative and to a partial change of the constitution).

Another modification was made in 1981. It extended the scope of the popular initiative, which, from that time, was not only to be used to adopt a new constitution, but also to introduce individual constitutional amendments (Matyja, 2019).

The current Federal Constitution of the Swiss Confederation was enacted in 1999. When it comes to the position of the parliament, there were no radical changes; "in this regard Switzerland remained faithful

\footnotetext{
${ }^{7}$ Cf. Die Bundesverfassung von 1874, Historisches Lexikon der Schweiz, http://www.hls-dhsdss.ch/textes/d/D9811.php, accessed October 10, 2019.

8 Die Bundesverfassung von 1874, Historisches Lexikon der Schweiz, http://www.hls-dhsdss.ch/textes/d/D9811.php, accessed August 10, 2019.
} 
to its political tradition and retained the foundations of the system established by the constitution of 1848" (Sarnecki, 2003: 7).

On December 18, 1998, the Federal Assembly proposed a draft of the new federal constitution. It was accepted by the nation and the cantons in the obligatory referendum on April 18,1999, and it came into effect on January 1, 2000. In this way, after 125 years, the Constitution of 1874 was replaced. It should be emphasized that the basic values of the Swiss democracy, such as federalism, direct democracy, welfare state and liberal rule of law were retained and only adjusted to adhere to modern times. The fundamental principles of the 1999 constitution are: human dignity as the state's highest value, welfare state, free competition and subsidiarity (Baumann/Stolz, 2007). The constitution consist of a preamble and six clearly formulated titles:

- Title I: General Provisions

- Title II: Fundamental Rights, Citizenship and Social Goals

- Title III: Confederation, Cantons and Communes

- Title IV: The People and the Cantons

- Title V: Federal Authorities

- Title VI: Revision of the Federal Constitution and Transitional Provisions

The new constitution retained the "three-level" political system made up of the communes, the cantons, and the federation. Although the fundamental territorial and political units are the cantons, a lot of weight is attached to the political and administrative role of the communes. ${ }^{9}$

The fundamental value of the Swiss constitution lies in the fact that it does not question the legal identity of the cantons. As Bohdan Górski rightly states: "The constitution does not turn against patriotism or attachment to the regional culture and identity. On the contrary, it integrates patriotism into the federal system, where it is a great force in service of a given canton and the Confederation" (Górski, 2013: 7879).

As I have already mentioned, Switzerland is a very diverse country in every respect. This diversity is the source of the specific role of the constitution, which - unlike in other countries - is not only a normative act, but also the actual foundation of the integration process and identity of the Helvetic state. It cannot be forgotten that the Swiss nationality is based on the will of its citizens, which is one of the reasons why the principles expressed in the Constitution are so significant.

\footnotetext{
${ }^{9}$ The communal tasks include: appointment of the authorities, management of assets through agreements, public finance, imposition and collection of taxes, granting citizenship, primary and secondary public education, maintenance and establishment of educational facilities, appointment of education authorities and teachers, public healthcare and social welfare, provision of commonly accessible non-specialist healthcare, provision of essential means of subsistence to the needy, maintenance of public peace and order, local planning, formulation of area development plans and issuing location decisions, organization of public works, establishment, development, and maintenance of industrial services, as well as technical, cultural and recreational infrastructure, author's note.
} 


\section{2) The Main Political Institutions in Switzerland}

\section{a) The Parliament}

As it has already been mentioned, the state's legislative power lies in the hands of the bicameral parliament called the Federal Assembly, elected for a term of four years. The parliament comprises of the National Council (the small chamber) and the Council of States (the larger chamber). Similarly to other countries, it functions as the legislature by passing bills and amendments to the constitution.

The National Council is composed of 200 representatives elected in general elections based on a system of proportional representation. The cantons are the constituencies from which representatives are elected to the National Council. The number of deputies per canton is - in accordance to the principle of electoral equality - proportional to its population.

The Council of States comprises 46 members elected by cantonal legislative assemblies for a term of one to four years. Each canton elects two representatives to the larger chamber, while a half-canton elects one representative. The elections are based on the majority rule and a two-round system (an absolute majority is required in the first round and a simple majority in the second round).

Both chambers have equal rights, and both may initiate legislative procedures or supervisory actions. On the other hand, every legal act has to be approved by the two chambers. Thus, a bill does no become a law if it is not passed both by the smaller and the larger chamber. A bill is always a result of compromise between the chambers. Each chamber is chaired by the president, elected for a term of one year without the possibility to be re-elected. The president, aided by two vice-presidents, chairs the sessions of a given chamber. When a tied vote occurs in any chamber, the president's vote is decisive. The parliament elects the Federal Council (the government), the Federal Supreme Court (for a term of five years), the Federal President from among the members of the Federal Council (despite it being a rotary function, it has to be approved by the parliament) and a general Commander of the army in case of a direct national threat. Among the supervisory functions of the Federal Assembly is the overview of the government's and the Federal Supreme Court's activity, as well as the adoption of the government's budget. The parliament also supervises the cantons, takes measures to safeguard external and internal security, and ratifies international treaties and agreements (Frey, 2005).

Interestingly, the Swiss political system provides an advantage to the parliament, mainly through the rejection of the idea of a necessary organizational separation of powers (Rocca, 2012; 7ff). This stems from the multifaceted role of the parliament, which not only carries out the legislative, supervisory, and judicial tasks, but also manages and governs the state. Unlike other parliamentary systems, Switzerland lacks such parliamentary limitations as shortening the terms, summoning and closing the sessions by the executive, constitutional courts or judicial control of elections (Podolak, 2013: 173). 
b) The Federal Council and the Federal President

In Switzerland, the Federal Council functions as the government. The Article 174 of the Federal Constitution of 1999 describes it as "the supreme governing and executive authority of the Confederation." In practice, the Federal Council, consisting of 7 members, is more of a coordinator than a government when compared to those in other democratic countries. The Council is elected by the Federal Assembly for a term of four years. The process of determining its composition follows the socalled magic formula.

The Federal Council is a collective agency, which means that any binding decision has to be made at a session with all members present. Voting always is preceded by a discussion. Such a method stems from the principle of equality of the ministerial offices - the ministers take decisions jointly. The collective nature of the Council means that its members are not personally responsible for the decisions. Some people maliciously say that actors earn more than the Swiss ministers because the latter do not play any role.

Due to the multitude of its duties, the parliament forms federal departments (their counterparts in other countries are called "ministries"), which are headed by the members of the Federal Council. ${ }^{10}$ The departments' activity is supervised and criticized by the parliament, or, to be more precise, by its supervisory committees. It is an essential factor that the heads of the departments cannot be dismissed by parliament. Parliament has the right to set tasks for the Federal Council through resolutions and postulates. A resolution may be issued by any chamber, although the other has to approve it anyway. Such a document obliges the Federal Council to submit a draft of a federal bill or to issue a binding recommendation. It is necessary for the government to examine a particular case and to submit a report containing a plan of further actions.

The functioning of the government is based on the principle of joint authority and cooperation in decision-making. The constitution does not provide the office of the prime minister. The government's tasks consist of the overview of foreign policy, including the question of neutrality, internal affairs, and security, which includes the command of the federal army. The administrative matters comprise the overview of the activity of all federal public officials. This involves such tasks as the execution of the constitutional provisions, as well as the application of acts and resolutions of the parliament. The Council also has legislative (e.g., issuing executive orders, provided that the agency is authorized to do that by the constitution or an appropriate law) and supervisory competencies in relation to the cantonal authorities.

\footnotetext{
${ }^{10}$ There are the following departments in Switzerland: Federal Department of Foreign Affairs, Federal Department of Home Affairs, Federal Department of Justice and Police, Federal Department of Finance, Federal Department of Economic Affairs, Education and Research, Federal Department of Environment, Transport, Energy and Communications, Federal Department of Defense, Civil Protection and Sports, author's note.
} 
The Federal Council does not function as a typical government since it is not politically liable to the parliament, which strengthens its position even further. When it comes to its supervisory role, the Swiss parliament is limited to merely a control and criticism of the government and its activities. The Swiss political system lacks the instrument of the vote censure on the government. The non-existence of the political responsibility on the part of the Federal Council is justified on the basis of the principle of cooperation and consensus between the political parties represented in the government (Gabriel, 1997). The members of the Federal Council decide between themselves about their dismissal or retirement, which, naturally, has its disadvantages. Usually, they resign from their ministerial office when they sense that they have lost their political party's support.

Every year, the Federal Assembly of the Swiss Confederation elects the president from among the members of the Federal Council, and the person elected retains the membership in the Council. The institution of the federal president lacks political significance. A minister who serves as the president still heads their department. Although the federal president heads the Federal Council, he is not the head of state and does not function as the prime minister. A federal vice-president is elected from among the members of the Council and has virtually no competencies apart from substituting for the president in case of indisposition.

The competencies of the federal president include conducting the works of the Council and preliminary examination of issues presented by particular departments. The most important function is to represent the Swiss state abroad. Due to the fact that the federal president is elected every year and plays no significant role in the state's decision-making, citizens often do not know who the current president is. Some authors and political scientists erroneously compare the position of the federal president in Switzerland to the position of presidents in other countries; this is because they ignore the term "federal," which explicitly point to the president's role as the head of the Federal Council and not the head of state.

\section{c) The Federal Supreme Court}

Located in Lausanne, the Supreme Federal Court is the chief judicial authority in Switzerland. ${ }^{11}$ It was established for the first time as an autonomous agency by the constitution of 1874 . As the highest echelon in the federation, it decides on matters of criminal, civil, administrative and constitutional law; it also ensures uniform applications of law in individual cantons. The autonomy of the Federal Supreme Court is expressed in its function as an administrative agency that oversees the federal courts: the Federal Criminal Court, the Federal Administrative Court, and the Federal Patent Court. ${ }^{12}$

The characteristic trait of the Supreme Federal Court is that it examines citizens' complaints concerning the violation of their constitutional rights by laws issued by cantonal authorities. The procedure is quite

\footnotetext{
${ }^{11} C f$. Article 188, Section 1 of the Federal Constitution.

${ }^{12}$ Ibidem.
} 
commonly used by the Swiss citizens. In this way, they directly control and modify the laws of the federation.

\section{3) The Swiss Federalism}

As it has already been mentioned, Switzerland's political system has three essential levels: the federation, cantons, and communes. It functions on the basis of a decentralized federalism that follows the principle of subsidiarity. This means that all decisions are made in a grassroots manner, with the direct participation of citizens (Blöchliger, 2005). The decisions that cannot be made on the communal level are made by the cantonal authorities. It has become a rule in many areas that the federal government makes law, but it leaves its implementation to the cantons, and they carry out this procedure according to their own regulations. Switzerland's strong federalist tradition expresses itself in the fact that each canton's authorities focus only on their own problems without criticizing other cantons (Linder, 2005). The cantons cannot be compared to provinces or administrative districts in other democratic countries, such as the French districts. This is because they are, in essence, independent, territorial units that resemble - and consider themselves as - separate states (German Staat, French l'Etat). They have all rights characteristic of a state, apart from those that they voluntarily waived to the federation (Schulze, 2012). It should be emphasized, though, that - as many representatives of the cantons have noticed from 1848 the number of rights of the federation has been growing, while the number of the rights of the cantons has been diminishing. According to the general political tradition of Switzerland, the higher instances of the government should relegate as much political tasks as possible to the lower instances (Matyja, 2009: 15), and the cantons should retain their constitutions, parliaments, governments, as well as financial and tax sovereignty intact. Moreover, the cantons, apart from making and implementing their own laws, are obliged to implement the federal laws.

The basis of the Swiss political culture is the principle of proportionality and consensus that apply to the representation through political parties and to officially used languages. This allows to create a legal environment free of conflicting regulations on all three administrative levels, as well as in regard to local minorities.

The Swiss mentality is characterized by a strong sense of local and political affiliation. Citizens identify themselves first and foremost with their commune and canton.

The system is undoubtedly organizationally complex and costly, but, in practice, it generates an authentic participation of citizens in the political life of the country, giving them satisfaction of making decisions on the matters that directly affect them (Kirchgässner et al., 1999)

The Swiss Federation consists of 26 cantons with a very diverse social, linguistic, religious, and cultural profiles. Among other tasks, a cantonal government supervises the communes, approves a budget, implements federal laws, appoints crucial cantonal officials, and controls important financial operations. 
The legislative authority is a cantonal council, i.e., a cantonal parliament comprising of 100 deputies, elected for a term of four years by the canton's citizens in general elections.

A cantonal government usually consists of 5-9 members who head a number of departments. It is obliged to enforce the decisions of the cantonal council, supervise the administration of the canton, provide advice to the communes, organize elections and referenda, and appoint lower cantonal officials.

An analysis of the Swiss political system cannot omit the particular role that the communes play as the foundation of the country. Historically, the communes were the first Swiss political units, and only as the result of acquiring new lands or conquest, the cantons were established. All rural and urban communes have retained their rights up to this day, and their sovereignty is guaranteed by the constitution. There are many structural similarities between the communes in all cantons. A communal assembly comprises of all citizens eligible to vote. Depending on the laws of the canton it belongs to, it either has the direct legislative power or it appoints a body of representatives with such power. An assembly approves the communal budget and supervises its execution, it also enacts taxes, appoints the communal authorities and supervises their activity, and accepts reports on the communal agencies' activity (Linder, 2005).

A communal assembly's sessions are called by its executive agency. The sessions divide into normal and special ones. A normal session takes place on dates pre-established by communal regulations or its executive agency. A special sessions is called whenever it is necessary by the commune's executive agency or by a motion put forward by the majority of citizens eligible to vote. The sessions are headed by the president of the commune. A general assembly, as a direct legislative agency, exists only in several, minor communes. The typical model is the so-called special model of communal organization, existing in the majority of the communes. It replaces the assembly with a communal parliament, elect by the communal assembly for a term of 2-4 years. The number of its members is set by the assembly, and it is chaired by the communal president. The mode of its sessions is similar to the one of the communal assemblies'. Thus, the majority of assemblies' competencies were transferred the communal parliaments. However, the fundamental matters such as budget, taxes, and appointment of the communal officials, are still decided on by the assemblies.

The executive agency of the commune is the communal council, and its 3-9 members are elected by the assembly. The council is headed by the communal president, who also is the head of the assembly. From a formal point of view, the president has the same competencies as other members of the council. The term of office of the council is concurrent with the term of office of the executive agencies of the canton. The internal structure of the council is similar to the one of the cantonal government. Its members, apart from the president, also head specific departments.

\section{4) The Party System and the "Magic Formula"}


One of the fundamental characteristics of the Swiss political system is the cooperation of the political parties which boils down to gaining seats and appointing a common cabinet. This is based on a kind of friendly agreement, which means that, although all parties represented in the parliament rule jointly, the cabinets are not coalitional. There is no parliamentary opposition in Switzerland. The process of creating a cabinet follows a so-called magic formula (Ger. Zauberformel): 2/2/2/1 - three parties with the largest number of seats gained provide two members each and the fourth party provides one member (Neidhart, 2002).

The magic formula results in the fact that, despite different election results, there are essentially four main parties that have been wielding power since 1959 and that represent 70 percent of society:

- Sozialdemokratische Partei der Schweiz SP (Social Democratic Party of Switzerland),

- Freisinning-Demokratische Partei FDP (Liberal Democratic Party of Switzerland),

- Christlichdemokratische Volkspartei CVP (Christian Democratic People's Party),

- Schweizerische Volkspartei SVP (Swiss People's Party).

Every canton has a different set of parties, and, moreover, every party has members with different political views. This stems from the fact that the electoral system does not favor a strong party discipline. Since in Swiss elections people vote directly for individuals, the issue of which political party gains the most votes and the people's trust is of secondary importance. Therefore, candidates are aware that, if they are elected, it is because of their personal traits. Parties often reach agreements to propose a number of candidates that matches the number of seats. In such a situation, cantonal governments consider the candidates as elected and do not organize elections.

If we take a look at other countries, minor members of parliamentary coalitions usually do not play a significant role in the political process. In Switzerland, it is the people themselves who constitute the political opposition to the government - by expressing their will through the instrument of direct democracy called referendum.

\section{5) The Instruments of Direct Democracy}

Due to the constitutional legislation and specific instruments of referendum and popular initiative, the Swiss have become the true sovereign whose voice matters in every important issue: from the communal level to the federal, like amending the constitution etc. This collective system of governance and considerable influence of interest groups and citizens has no counterpart in other countries (Möckli, 2007).

The idea of citizens' participation in political decision-making through direct democracy is the essential part of Switzerland's past. The democratic instruments in this country are:

- people's assembly,

- popular initiative, 
- referendum,

- people's veto.

It is worthy of notice that between 1848 and 2010 the instruments were used 570 times. $^{13}$

Even though other countries have systems resembling direct democracy, they cannot be compared due to the Swiss system due to its specific nature and complex grass-roots decision-making (Kost, 2008).

This leads us the difficult task of defining an efficient democratic system based on the instruments grounded in the principle of subsidiarity (Meyer, 2009). In Switzerland, almost every federal act may be submitted to a referendum, which enables citizens to verify the parliaments decision on the national level and to oblige the legislators to modify a given act. These instruments enable citizens to supervise their representatives and the political elites. The issues submitted to referenda vary from minor ones to really important. This is because the Swiss have a vast freedom to make any political issue the subject of popular initiative. As a result, the rulers are not afraid to take on difficult problems, even if it means that they will not get re-elected. In such system, they simply lack incentives to act in a conformist manner.

\section{a) Popular's Initiative}

The instrument of popular initiative plays a key role in the Swiss model. In general, it allows 100,000 citizens eligible to vote to demand amending the constitution, to propose a new bill, or to repeal an act. An initiative may concern both particular and general issues. If there is a proposal, it is first discussed in the Federal Council and the Federal Assembly. The two bodies issue a formal statement regarding the proposed changes by making different proposals or expanding the initial one. Next, all initiatives and their counterproposals are submitted to the vote of the people and the cantons in a referendum. If the majority of them votes "yes", then the proposal is accepted.

The Swiss political systems distinguishes two types of an initiative: one to adopt a new constitution and one that aims at amending the currently functioning constitution. The former was introduced in 1848 , while the latter - in 1891. Both Articles 138 and 139 of the Constitution - concerning the initiative to adopt a new constitution and the initiative to partially amend the Federal Constitution respectively state that such proposals may be put forward by 100,000 citizens eligible to vote. ${ }^{14}$ The initiative

13 Data according to the Swiss Federal Statistical Office in Neuchâtel, http://www.bfs.admin.ch/bfs/portal/de/index/themen/17/03/blank/key/eidg__volksinitiativen.html, accessed June 10, 2019.

${ }^{14}$ Article 139 reads as follows: Popular initiative requesting a partial revision of the Federal Constitution. 1. Any 100,000 persons eligible to vote may request a partial revision of the Federal Constitution. 2. A popular initiative for the partial revision of the Federal Constitution may take the form of a general proposal or of a specific draft of the provisions proposed.3. If the initiative fails to comply with the requirements of consistency of form, and of subject matter, or if it infringes mandatory provisions of international law, the Federal Assembly shall declare it to be invalid in whole or in part. 4. If the Federal Assembly is in agreement with an initiative in the form of a general proposal, it shall draft the partial revision on the basis of the initiative and submit it to the vote of the 
concerning a partial amendment may consist of a general proposal or specific provisions. Is the initiative is at odds with the national and international laws, the parliament may declare it wholly or partially invalid. Otherwise, it draws up amendments, according to the proposed direction of changes, and submits it to the assessment of the people and the cantons. If the parliament does not agree with the initiative, it submits the proposal to the vote of the people who then decide whether it should be processed further. In case of a positive result, the parliament draws up proper amendments. A ready project of constitutional amendments is decided upon by the people and the cantons. The parliament offers advice on whether the initiative should be accepted or rejected. If the latter is the case, the parliament may make a counterproposal, which is then submitted to the vote of the people and the cantons at the same time as the initial proposal. The voters may accept both proposals or point the one that they would like to be approved in case both of them are accepted. If one of the proposals gets the majority of the people's votes and the other gets the majority of the cantons' votes, both are rejected.

\section{b) Referendum}

Switzerland has two types of referenda: mandatory, also known as constitutional, and optional, also called legislative (Degen, 2011: 166-168).

Mandatory referendum was introduced already in 1848, and it is used in case of a necessity to amend the constitution. Since 1977, it is also used to decide on joining international organizations. Article 140 item 2 of the Constitution defines the use of the mandatory referendum:

The following are submitted to a vote of the People:

a. popular initiatives for a total revision of the Federal Constitution;

b. popular initiatives for a partial revision of the Federal Constitution in the form of a general proposal that have been rejected by the Federal Assembly;

c. the question of whether a total revision of the Federal Constitution should be carried out, in the event that there is disagreement between the two Councils.

The people and the cantons express their will on issues such as: revision of the Federal Constitution, accession to organizations for collective security or supranational communities, emergency federal acts

People and the Cantons. If the Federal Assembly rejects the initiative, it shall submit it to a vote of the People; the People shall decide whether the initiative should be adopted. If they vote in favor, the Federal Assembly shall draft the corresponding bill. 5. An initiative in the form of a specific draft shall be submitted to the vote of the People and the Cantons. The Federal Assembly shall recommend whether the initiative should be adopted or rejected. It may submit a counter-proposal to the initiative. And further: the People vote on the initiative and the counterproposal at the same time. The People may vote in favor of both proposals. In response to the third question, they may indicate the proposal that they prefer if both are accepted. If in response to the third question one proposal to amend the Constitution receives more votes from the People and the other more votes from the Cantons, none of them is approved, The Federal Constitution of the Swiss Confederation, http://www.admin.ch/opc/de/classifiedcompilation/19995395/index.html\#a8, accessed April 23, 2019, author's note. 
that are not based on a provision of the Constitution and whose term of validity exceeds one year (such federal acts must be put to the vote within one year of being passed by the Federal Assembly).

The people are the only decision-maker when it comes to: popular initiatives for a total revision of the Federal Constitution, popular initiatives for a partial revision of the Federal Constitution in the form of a general proposal that have been rejected by the Federal Assembly, and the question of whether a total revision of the Federal Constitution should be carried out, in the event that there is disagreement between the two Councils.

\section{c) People's Veto}

Optional referendum, also called people's veto, was introduced in 1874 and is used to oppose already existing laws. According to Article 141 of the Constitution, it requires 50,000 citizens or at least eight of the cantons to be organized. The issues that are submitted to the vote are: federal acts, emergency federal acts whose term of validity exceeds one year, federal decrees (provided the Constitution or an act so requires), international treaties that are of unlimited duration and may not be terminated, provide for accession to an international organization, contain important legislative provisions or who implementation requires the enactment of federal legislation. The Constitution also allows to submit to the vote other international agreements. According to Article 142, proposal that are submitted to the vote of the People are accepted if a majority of those who vote approve them (Hug, 2004:321-360). For instance, in 2000-2010 mandatory and optional referenda were used 45 times (Marczewska-Rytko, 2012: 272-283). The people and the cantons approved the proposal in 11 of them and rejected in four. ${ }^{15}$

\section{6) Efficiency of Swiss Direct Democracy}

The functionality of direct democracy closely related to the widespread and conscious participation of citizens and political actors in the state, cantonal, and communal decision-making.

Firstly, direct democracy makes citizens' participation in political decision-making easier. It allows even entities outside the governmental structures to influence the political process (Möckli, 1995: 9).

Secondly, every political actor is able to put forward its demands efficiently. Even those initiatives and referenda that have no chance of success are organized, because they provide a political input that shapes the public opinion (Vatter, 2014: 358ff).

Thirdly, direct democracy incentivizes rulers to make compromises and to take into account the public's opinions (Möckli, 1995: 10). It means that politicians, from fear of being a "victim" of a popular

15 Data according to the Swiss Federal Statistical Office in Nauchâtel: http://www.bfs.admin.ch/bfs/portal/de/index/themen/17/03/blank/key/eidg__volksinitiativen.html, accessed June $10,2019$. 
initiative, are in constant contact with the rest of society. This is particularly advantageous for minorities by enabling them to successfully submit their own proposals.

Fourthly, in direct democracy, final decisions are widely accepted by all actors in the political, economic, and social scene. A decision made via a referendum is much more likely to be supported by the whole society than one pushed forward by political elites.

Fifthly, direct democracy has two important functions when it comes to decision-making: political communication and political socialization (Möckli, 1995: 11). The former, due to the vast number of political actors engaged in decision-making, facilitates the growth of society's political awareness to a level that cannot even be compared with representative democracies. Another factor at work here is the tendency to make compromises, which creates a net of political and social connections where information is constantly exchanged. Political socialization means that society's participation in direct democracy makes it more conscious of its democratic rights and freedoms, such as respecting the arguments of their political opponents.

The problem of dysfunctionality of certain aspects of direct democracy is complex and multileveled. Firstly, although it allows a wide participation of citizens in the political life of their country, only a small minority actually takes part in this process. It is a group of citizens who, regardless of the political system, would take the political initiative and engage in decision-making anyway. This minority consists of political elite, the so-called classe politique, whose opinions and views are usually respected by the majority of society. Therefore, general political input in direct democracy is not that much different than in representative-parliamentary democracy (Möckli, 1995: 12).

Secondly, direct democracy makes decision-making slower, which may obstruct the process of finding desired solutions. Due to the fact that the political process in direct democracy has so many actors (political parties, interest groups, society), it has to make compromises. Moreover, political elites are not keen on including the representatives of society in decision-making, but, to the contrary, they tend to limit the number of referenda out of fear of unprofitable decisions made at the polling stations.

Thirdly, direct democracy undermines the position of the established political actors by enabling the people to bypass certain state agencies in exercising their will. The system empowers the opposition and, as a result, makes much more rare for political opponents to negotiate, discuss, or compromise on their agendas.

This allows the interest groups to push forward proposals that will be beneficial to them, while bearing no political responsibility for the outcomes. The groups, standing between society and political parties, become a competition for the latter, undermining their power.

Fourthly, the multiplicity and diversity of decisions made in direct democracy causes society to become passive. The voters are unable to properly exchange information about all occurring changes, because as it would generate high costs. Usually, on the day before a referendum, only one-sixth of the Swiss voters are fully informed about the issues they are about to decide on (Möckli, 1995: 14). 
Fifthly, direct democracy can exacerbate political conflicts in the country. This is especially possible when a referendum concerns issues of "all-or-nothing" nature. This creates a risk of inflaming political struggles, and sometimes leads to oppressing the minority by the majority (Matyja, 2014).

\section{Conclusion}

The question whether the federal system of Switzerland has more advantages or disadvantages requires an ideological discussion, because it cannot be directly compared with the political systems of other countries. The Swiss federalism has so many aspects that, depending on a currently adopted point of view, they may seem both positive and negative (Matyja, 2016).

Due to the multicultural character of Switzerland, it would be difficult to achieve its current level of political and social consensus without its particular form of federalism. The system ensures a fair treatment of all ethnic, religious, and linguistic minorities. Since many decisions are made at the lowest political level, citizens are protected from unjust or harmful interferences of the state (Matsusaka, 2000: 157-177).

Federalism thwarts cultural and ethnic conflicts, and allows the state to adjust its activities to the regional differences. The rare occurrence of any regional tensions or political conflicts are the best evidence of the efficient and fully democratic functioning of the Swiss federal state. Despite the fact that the process of negotiations between the cantons, as well as between the federation and the cantons, is often long and slow - which is incomprehensible to foreign observers - it leads to positive results (Eichenberger, 2002). The costs of the Swiss system are certainly one of its main downsides. Each of the cantons has its own government, administration, judiciary etc. - even the universities are funded by the cantons. Although it is not an ideal system, the internal and international situation of the country shows that the Swiss would not replace it with any other - even in the face of globalization and increasing European integration. Switzerland protects its cantons' competencies and its direct democracy in a consistent manner, and in case of inter-cantonal conflicts it always looks for peaceful solutions - such as the intercantonal agreement called "concordat" (Fenner/Hadorn/Strahm, 2000).

The Swiss model of democracy is the best example for other countries, which are looking for new political solutions.

\section{References}

[1] Aleksandrowicz M., System prawny Szwajcarii: historia i współczesność, Białystok 2009.

[2] Baur A., Fenomen szwajcarski, Warszawa 1979.

[3] Blöchliger H., Kantone - Baustelle Föderalismus. Metropolitanregionen versus Kantone. Untersuchungen und Vorschläge für eine Revitalisierung der Schweiz, NZZ Libro, Zürich 2005.

[4] Büchi R., Braun N., Kaufmann B., Przewodnik po demokracji bezpośredniej, Initiative \& Referendum Institute Europe, Łódź 2013. 
[5] Czeszejko-Sochacki Z., System konstytucyjny Szwajcarii, Wydawnictwo Sejmowe, Warszawa 2002.

[6] Czeszejko-Sochacki Z., Wstęp, in: Konstytucja Federalna Konfederacji Szwajcarskiej z dnia 18 kwietnia 1999 r., translation and introduction: Z. Czeszejko-Sochacki, Warszawa 2000.

[7] Degen B., Referendum, entry in: Historisches Lexikon der Schweiz, Bd. 10: Pro-Schafroth, Schwabe, Basel 2011, p. 166-68.

[8] Eichenberger R., Starke Föderalismus. Drei Reformvorschläge für fruchtbaren Föderalismus, Orell Füssli, Zürich 2002.

[9] Eine Schweiz - viele Religionen. Risiken und Chancen des Zusammenlebens, Ed. M. Baumann, J. Stolz, Transkript, Bielefeld 2007.

[10] Fenner M., Hadorn R., Strahm R.H., Politszene Schweiz. Politik und Wirtschaft heute, Verlag für Sozialwissenschaft, Basel 2000.

[11] Frey R.L., (ed.), Föderalismus - Zukunftstauglich?!, NZZ Libro, Zürich 2005.

[12] Gabriel J.M., das politische System der Schweiz, Haupt, Bern 1997.

[13] Górski B., Jak przeżyć kapitalizm, Retro-Art., Warszawa 2013.

[14] Grenzen des Zumutbaren. Erfahrungen mit der französischen Okkupation und der Helvetischen Republik (1798-1803), Ed. A. Würgler, Schwabe Verl., Basel 2011.

[15] Hug S., Occurrence and Policy Consequences of Referendums, "Journal of Theoretical Politics" 2004, vol. 16, p. 321-36.

[16] Kirchgässner G. (ed.), Die direkte Demokratie. Modern, erfolgreich, entwicklungs und exportfähig, Helbing \& Lichtenhahn, Vahlen, Basel-Genf-München 1999.

[17] Kost A., Direkte Demokratie, Verlag für Sozialwissenschaft, Wiesbaden 2008.

[18] Linder L., Schweizerische Demokratie. Institutionen - Prozesse - Perspektiven, Haupt, BernStuttgart-Wien 2005.

[19] Manatschal V. A., Kantonale Integrationspolitik im Vergleich. Eine Untersuchung der Determinanten und Auswirkungen subnationaler Politikvielfalt, Nomos, Baden-Baden 2013.

[20] Marczewska-Rytko M., Inicjatywa ludowa i referendum w Szwajcarii w latach 2000-2010, "Polityka i Społeczeństwo" 2012, no. 9, p. 272-83.

[21] Marczewska-Rytko M., Szwajcarski model demokracji bezpośredniej, in: Stan i perspektywy demokracji bezpośredniej we współczesnym świecie, M. Marczewska-Rytko (ed.), Lublin 2011.

[22] Matsusaka J.G., The eclipse of legislatures. Direct democracy in the $21^{\text {st }}$ century, "Public Choice" 2000, vol. 124, p. 157-77.

[23] Matyja M, Swiss Made. Jak funkcjonuje międzykulturowa Szwajcaria?, Poligraf, Brzezia Łąka 2010.

[24] Matyja M., Besonderheiten des politischen Systems der Schweiz. Föderalismus und direkte Demokratie, "Europa Regionum" 2009, no. 12, p. 15.

[25] Matyja M., Dysfunkcjonalność szwajcarskiej demokracji bezpośredniej, Adam Marszałek, Toruń 2016.

[26] Matyja M., Granice demokracji bezpośredniej. Wpływ szwajcarskiego systemu demokracji bezpośredniej na proces integracyjny muzułmańskiej mniejszości religijnej, Poligraf, Brzezia Łąka 2014.

[27] Matyja M., Oddolna samorządność i partycypacja obywateli - specyfika systemu federalnego Szwajcarii, „Obywatel” 2009, no. 2, p. 46-47.

[28] Matyja M., Specyfika i efektywność szwajcarskiego systemu demokracji bezpośredniej, Adam Marszałek, Toruń 2019.

[29] Matyja M., Szwajcarski system federalny, "Stosunki Międzynarodowe", http://www.stosunki.pl/?q=content/szwajcarski-system-federalny, accessed February 28, 2019.

[30] Matyja M., Utopia or Chance? Direct Democracy in Switzerland, Poland and Other Countries, BoD, Norderstedt 2019.

[31] Meyer T., Was ist Demokratie, Verlag für Sozialwissenschaft, Wiesbaden 2009.

[32] Möckli S., Das politische System der Schweiz verstehen, Tobler, Altstätten 2007.

[33] Möckli S., Funktionen und Dysfunktionen der direkten Demokratie, "Beiträge und Berichte" 1995, no. 237. 
[34] Najstarsze konstytucje z końca XVIII i I połowy XIX wieku, translation and introduction: P. Sarnecki (ed.), Warszawa 1997.

[35] Neidhart L., Die politische Schweiz. Fundamente und Intituttionen, NZZ Libro, Zürich 2002.

[36] Podolak M., System polityczny Szwajcarii, in: Współczesne systemy polityczne, M. Żmigrodzki, B. Dziemidok-Olszewska (ed.), PWN, Warszawa 2013.

[37] Pogorzelska-Kliks A., Ewolucja tożsamości narodowej mieszkańców szwajcarskiego kantonu Valais, doctoral dissertation, Uniwersystet Śląski Wydział Nauk Społecznych, Katowice 2007.

[38] Roca R., Wenn die Volkssouveränität wirklich eine Wahrheit werden soll... Die schweizerische direkte Demokratie in Theorie un Praxis - Das Beispiel des Kantons Luzern, Schulthess Juristische Medien AG, Zürich/Basel/Genf 2012.

[39] Rybicki M., Konstytucja Związkowa Konfederacji Szwajcarskiej, in: Konstytucje Wielkiej Brytanii, Stanów Zjednoczonych, Belgii i Szwajcarii, Wrocław 1970.

[40] Sarnecki P., Zgromadzenie Federalne. Parlament Konfederacji Szwajcarskiej, Warszawa 2003.

[41] Schulze H., Państwo i naród w dziejach Europy, translation D. Lachowska, Wyd. Uniwersytetu Warszawskiego, Warszawa 2012.

[42] Tasențe T. (2019) Social Media și comunicarea politică personalizată, Editura Universitară, București, 2019

[43] Vatter A., Das politische System der Schweiz, Nomos, Baden-Baden 2014.

[44] Wojtowicz J., Historia Szwajcarii, Wrocław - Warszawa - Kraków - Gdańsk 1976.

[45] Bundesblatt no. 34 of July 26, 1873, http://www.admin.ch/opc/de/federalgazette/1873/index_34.html, accessed August 10, 2019.

[46] Die Bundesverfassung von 1874, Historisches Lexikon der Schweiz, http://www.hls-dhsdss.ch/textes/d/D9811.php, accessed August 10, 2019.

[47] Helvetische Staatsverfassung,

http://www.servat.unibe.ch/verfg/ch/1798_Helvetische_Staatsverfassung.pdf, accessed August 9,

2019. 